\title{
Introduction to the Management and Service of Industrial and Commercial Administration
}

\author{
Fu Hong \\ Jiangxi College Of Foreign Studies
}

\begin{abstract}
The rapid development of market economy and China's entry into WTO did not only bring opportunities and challenges for the enterprises of China, but also brought opportunities and challenges for the industrial and commercial administration. In order to adapt to the change of government functions and the needs of the development of market economy, to improve the law enforcement and supervision and management of all levels of the industrial and commercial administration departments, to fully develop and use information resources of industry and commerce and to better provide service for economic construction and enterprise production and management, it is imperative to establish a highly integrated, information sharing, efficient and stable and advanced practical business management information system. This paper briefly introduces the concept and its development process of management information system (MIS). In view of the characteristics of industrial and commercial business, such as strong policy, complexity and variability, large and various information, different using levels, etc. this paper focuses on the importance of industrial and commercial administration in enterprise management.
\end{abstract}

Keywords-Industrial and commercial administration; Administration; Service; Economy; Enterprise

\section{INTRODUCTION}

With the rapid growth of the global economy, in knowledge economy, enterprise development needs to strengthen the human resource team construction. In the premise that the enterprise economic benefit hard index has been achieved, modern enterprise management also gradually begins to be mature. For the enterprises which maximize the value, the manager is the key to realize the goal of enterprise practitioners, which determines the enterprise managers hope the administrative department start from the development of enterprises in the management process and produce synergistic reaction which is conducive to enterprise management.However, due to the complicated economic transactions in modern society, the evolution trend is obvious. Competition and unfair competition may happen between enterprises at any time, which makes the management of enterprises face more challenges. And the management and service of the industrial and commercial administration can provide stable development space for enterprise management.

Only the soft power be developed can enterprises survive in such fierce society. To strengthen the personnel skills cultivation of units and departments at all levels of enterprises becomes a top priority. The routine activities organized by the industrial and commercial administration departments are helpful for enterprises to develop compound and innovative talents teams which are suitable in the trend of the development of modern society.

So this paper mainly expounds the industrial and commercial administration as the breakthrough point, talks about the importance of the industrial and commercial administration to the management and development of enterprises, and puts forward related personnel training to promote the the industrial and commercial administration level of enterprises and the countermeasures about the development of enterprises.

\section{THE INDUSTRIAL AND COMMERCIAL}

\section{ADMINISTRATION}

As an important branch of management science, according to the basic theories of management and economics,the industrial and commercial administration studies how to use modern management methods and means to carry out effective enterprise management and decision.Broad field of industrial and commercial administration contains many fields with characteristics secondary professionals, including industrial and 
commercial administration, marketing, accounting management, financial management,human resource management, tourism management, etc. Professional research directions are as follows:

1. The theory of modern enterprise and professional managers research:On the basis of modern property rights economics, be engaged in the study of basic theory and application.Research fields contain modern enterprise system, corporate governance structure, the formation and developing mechanism of professional managers, incentive and constraint mechanism, enterprise internal organization and management mechanism, etc.

2. Finance and financial management: Taking the coordinated development between enterprises and social environment and natural environment as the guidance, integrate multi-disciplinary resources and conduct basic theory and application research. Research fields contain the stakeholder theory and corporate finance, financial strategy, financial management, financial management information system development, human assets and intangible assets assessment, financial engineering, etc.

3. Enterprise resource economic and strategic management: Taking enterprise resource as the object, by means of strategic decision, integrate multi-disciplinary resources to conduct basic theory and application research. Research fields contain the enterprise resource planning and decision-making, the relationship between enterprise and social environment, strategic analysis and decision-making, etc.

4. Enterprise capital management: Taking the capital market as the platform and enterprise capital operation as the object, conduct

\section{ADJUST THE COORDINATION OF MANAGEMENT AND ACTIVELY COMPLETE THE SERVICE SYSTEM}

The basic theory and application research. Research fields are capital market, investment banking business, merger and acquisition and other ways of capital operation. Industrial and commercial administrative departments is to service the basis of commodity economy. Therefore, department of industrial and commercial administration does not only have to do a good job of supervision and management, but also has to actively do a good job in service system. Guide enterprise management personnel to get involved in the maintenance of the healthy development of the planned economy. Therefore, industrial and commercial administrative departments must unify management and service system in harmony and make effective management and good service. In the process of implementation, industrial and commerce administration should the administrative intervention in the past, and should increase the level of economic development and further improve the enterprise internal environment through positive propaganda, economic management and other methods. Industrial and commerce administration departments should uses the management model to dredge and guide, provide good service and finally stimulate economy, to achieve the purpose of strengthening the management work, so as to realize rapid, healthy and stable development.

In service management work, industrial and commercial management personnel must firstly change the style of work, strengthen the service consciousness, deepen the reality, set an example and put forward ideas for enterprises. Secondly, guide enterprises change business strategy, find out adaptation channels and enhance the vitality of enterprises. In addition, industrial and commercial administration departments shall actively use reasonable administration function to effectively provide service for enterprises. Finally, seriously govern

"three mess", optimize the charge standard, correct the charging items and cancel checkpoints without approvals, etc.

\section{ENTERPRISE REGISTRATION MANAGEMENT SYSTEM}

The supervision and management object of the Ministry of Commerce and Industry is the main body of the market. According to the nature, it can be divided into domestic enterprises, foreign-funded enterprises, private enterprises and individual households, among which, domestic enterprises include company, branch, enterprise legal person and enterprise group. The enterprise registration regulation of industry and commerce administration (hereinafter referred to as enterprises) of Henan Province is the functional departments of supervision and management of domestic enterprises. Its main responsibilities are to organize and manage enterprise registration, approve registration unit name, audit, issue the licenses of enterprises and other business units within the jurisdiction, supervise and inspect the 
registration behavior, guide and supervise the enterprise registration of the system and supervise the administration work.

Domestic enterprises registration management system has name management, registration management, supervision management, IC card management, query management, graphics files and data statistics, daily services, system maintenance and other function modules.

The function system structure of the domestic enterprise registration management is shown in Fig .1.

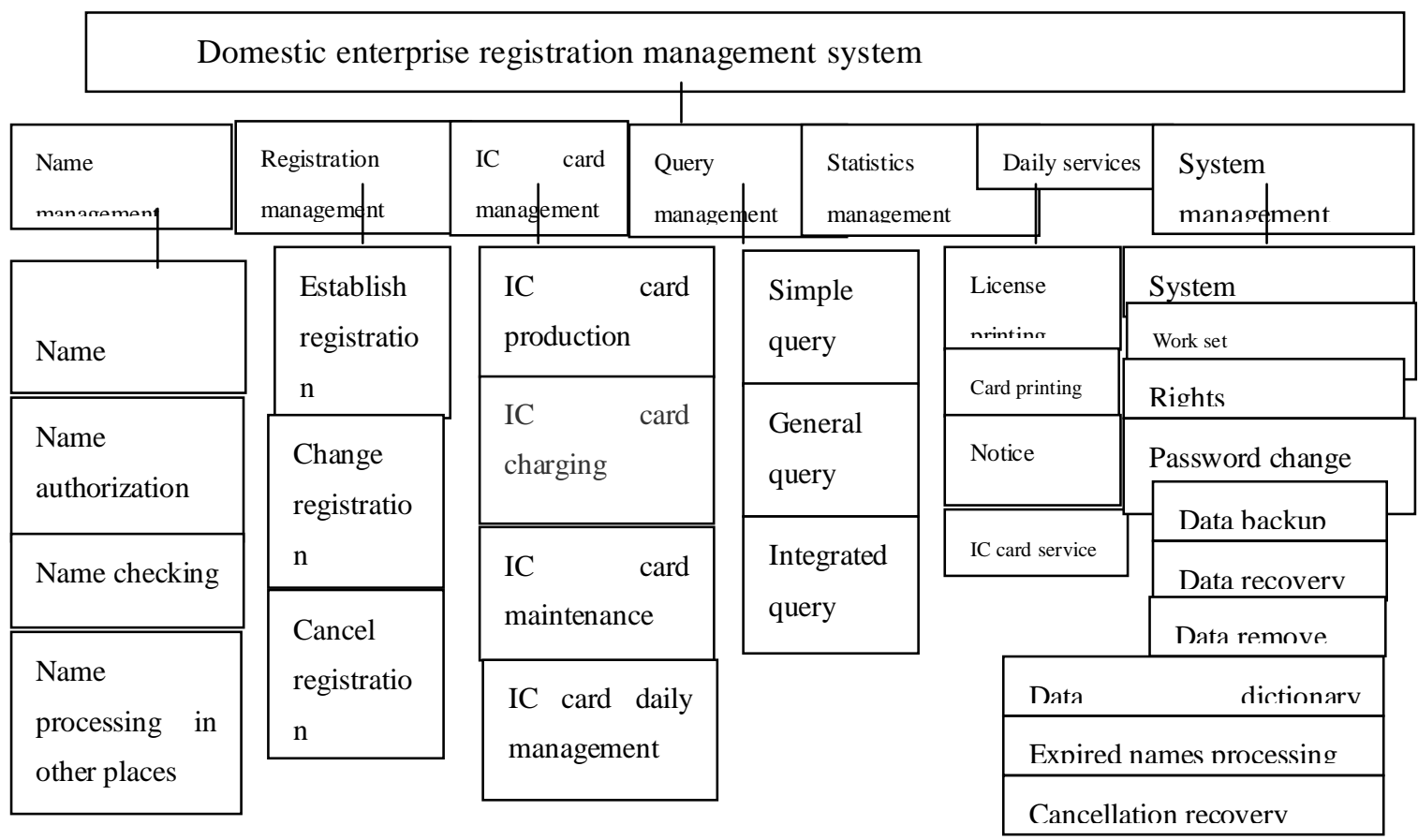

Figure 1. domestic enterprise registration management

\section{CONCLUSION}

Industrial and commercial administration is not only a discipline, but also the important content of human resource management in the human resources training construction of the modern enterprise management system. The competition in the market in our country steps into the access to the competition, market incentive competition degree is more and more high. If enterprises want to constantly absorb talents, and strengthen the training base of the professional skill quality of the employees at the same time, enterprises should strengthen the innovation of the industrial and commercial management training activities, in order to raise the level of enterprise management in the fierce competition in the market.

The paper can be summarized as follows: in the process of industrial and commercial administration, it is necessary to carry out reasonable control and govern enterprises, to actively set up encourage and competition consciousness to encourage the development of science and to set up competitive consciousness. The uniform of encouragement and competition can promote enterprises to develop well. At the same time, in the process of solution and the management, it is necessary to strengthen the service consciousness, correctly carry out the correct guidance and management. Only the coordination and implementation of the management can better promote the development of enterprises, so as to effectively solve the contradiction between managers and administrators.

\section{REFERENCE}

[1] Brunt, L., Lerner, J., Nicholas, T., Brunt, C. L., Lerner, J., \& Nicholas, T., et al. (2011). Norwegian school of economics and business administration. Journal of Industrial Economics, 60(4), 657-696.

[2] Williamson $\mathrm{O}$ E. Transaction cost economics and business administration[J]. Scandinavian Journal of Management, 2005, 21(1):19-40

[3] Chandler, Alfred D., and F. Redlich. "Recent Developments in American Business Administration and their Conceptualization." Business History Review 35.1(1961):103-130.

[4] Chandler, Alfred D., and F. Redlich. "Recent Developments in American Business Administration and their Conceptualization." Business History Review 35.1(1961):103-130.

[5] Aitken, Hugh G. J. "Recent Developments in American Business Administration and Their Conceptualization: A Discussion of the Chandler-Redlich Article (Spring, 1961, Business History Review)." Business History Review 35.3(1961):429-429.

[6] Ruby, Christabel Donatienne, Institute, and business. "Institute for Research in Economics and Business Administration." Management (2011). 
[7] Macharzina, Klaus, J. Wolf, and M. J. Oesterle. "Quantitative Evaluation of German Research Output in Business Administration." Management International Review 33.1(1993):65-83.

[8] Beckmann, Martin J., and M. J. Beckmann. "Returns to Scale in Business Administration." Cowles Foundation Discussion Papers (1958).

[9] Villas, Marcos Vianna, and G. M. Russo. "Bibliographical research method for business administration studies: a model based on scientific journal ranking." BAR. Brazilian Administration Review 5.Suppl 4(2008):139-159.
[10] Estrada J, Estrada J. SWEDISH SCHOOL OF ECONOMICS AND BUSINESS ADMINISTRATION[J]. Citeseer, 2006, 15(03):467-483.

[11] Grönroos, Christian, and A. Ravald. "The value concept and relationship marketing." European Journal of Marketing 30.2(1967):19-30.

[12] Simons, Roland, and K. Sveiby. "Collaborative climate and effectiveness of knowledge work - an empirical study." Journal of Knowledge Management volume 6.5(1997):420-433(14). 